\title{
The U.S.-Mexico Transboundary Aquifer Assessment Program as a Model for Transborder Groundwater Collaboration
}

\author{
Elia M. Tapia-Villaseñor ${ }^{1, *(D)}$ and Sharon B. Megdal ${ }^{2}$ \\ 1 Departamento de Geología, Universidad de Sonora, Hermosillo 83000, Mexico \\ 2 Water Resources Research Center, The University of Arizona, Tucson, AZ 85719, USA; smegdal@arizona.edu \\ * Correspondence: elia.tapia@unison.mx
}

Citation: Tapia-Villaseñor, E.M.; Megdal, S.B. The U.S.-Mexico Transboundary Aquifer Assessment Program as a Model for Transborder Groundwater Collaboration. Water 2021, 13, 530. https://doi.org/ $10.3390 /$ w13040530

Academic Editors: Frédéric Huneau

Received: 30 December 2020

Accepted: 10 February 2021

Published: 18 February 2021

Publisher's Note: MDPI stays neutral with regard to jurisdictional claims in published maps and institutional affiliations.

Copyright: () 2021 by the authors. Licensee MDPI, Basel, Switzerland. This article is an open access article distributed under the terms and conditions of the Creative Commons Attribution (CC BY) license (https:// creativecommons.org/licenses/by/ $4.0 /)$.

\begin{abstract}
The assessment of transboundary aquifers is essential for the development of groundwater management strategies and the sustainable use of groundwater resources. The Transboundary Aquifer Assessment Program (TAAP) is a joint effort by the United States and Mexico to evaluate shared aquifers. This study examines the TAAP Cooperative Framework as a guide for further transboundary groundwater collaboration. We compared lessons learned from six transboundary aquifers that currently have mechanisms for groundwater collaboration to identify common elements of collaboration. Though the TAAP Cooperative Framework governs an assessment-only program, the elements of collaboration included are consistent with the principles of other institutional agreements around the world. Importantly, all the analyzed agreements included a knowledge-improvement phase, which is the main objective of the TAAP Cooperative Framework. The present study finds evidence of successful outcomes within the TAAP Cooperative Framework consistent with available transboundary groundwater management agreements, demonstrating that this approach is suited to serve as a model for those wishing to engage in transborder aquifer assessments. Furthermore, the TAAP elements of collaboration can help to establish the meaningful and robust binational cooperation necessary for the development of U.S.-Mexico groundwater management agreements at the aquifer level.
\end{abstract}

Keywords: transboundary aquifers; United States; Mexico; assessment; agreements; groundwater management

\section{Introduction}

Groundwater is an important source of fresh water for populations and the environment. Fresh water represents only $2.8 \%$ of the total water resources in the world, with $70 \%$ of fresh water composed of polar ice layers and continental ice, $1 \%$ from surface watercourses, and $29 \%$ from groundwater [1]. Transboundary rivers, lakes, and aquifers are home to over $70 \%$ of the world's population and supply water for around $60 \%$ of global food production [2]. Approximately 600 transboundary aquifers have been identified around the world [3]. However, only six of them have formal binational or multinational mechanisms of cooperation: (1) the Guaraní Aquifer System in Brazil, Argentina, Paraguay, and Uruguay; (2) the Franco-Swiss Genevese Aquifer System in France and Switzerland; (3) the Northwestern Sahara Aquifer System in Algeria, Libya, and Tunisia; (4) the Iullemeden Aquifer System in Mali, Niger, and Nigeria; (5) the Nubian Sandstone Aquifer System shared by East Libya, Egypt, Northeast Chad, and North Sudan, and; (6) the Al-Saq/Al-Disi Aquifer System in Jordan and Saudi Arabia (Figure 1).

Although geographically widespread, these aquifers represent only $1 \%$ of identified transboundary aquifers, a proportion that is quite different from the proportion of transboundary river basins with international basin agreements. While there are 310 transboundary river basins around the world, a total of 688 transboundary basin agreements have been signed between 1820 and 2007 [4-6]. These agreements apply to 133 river basins, 
representing $36 \%$ of the identified transboundary basins [4]. The reasons for such a disparity between the number of basin agreements and the number of groundwater agreements include the "invisible" nature of groundwater $[7,8]$, limited and dissimilar groundwater data [9], and the lack of institutional capacity for groundwater governance [10].
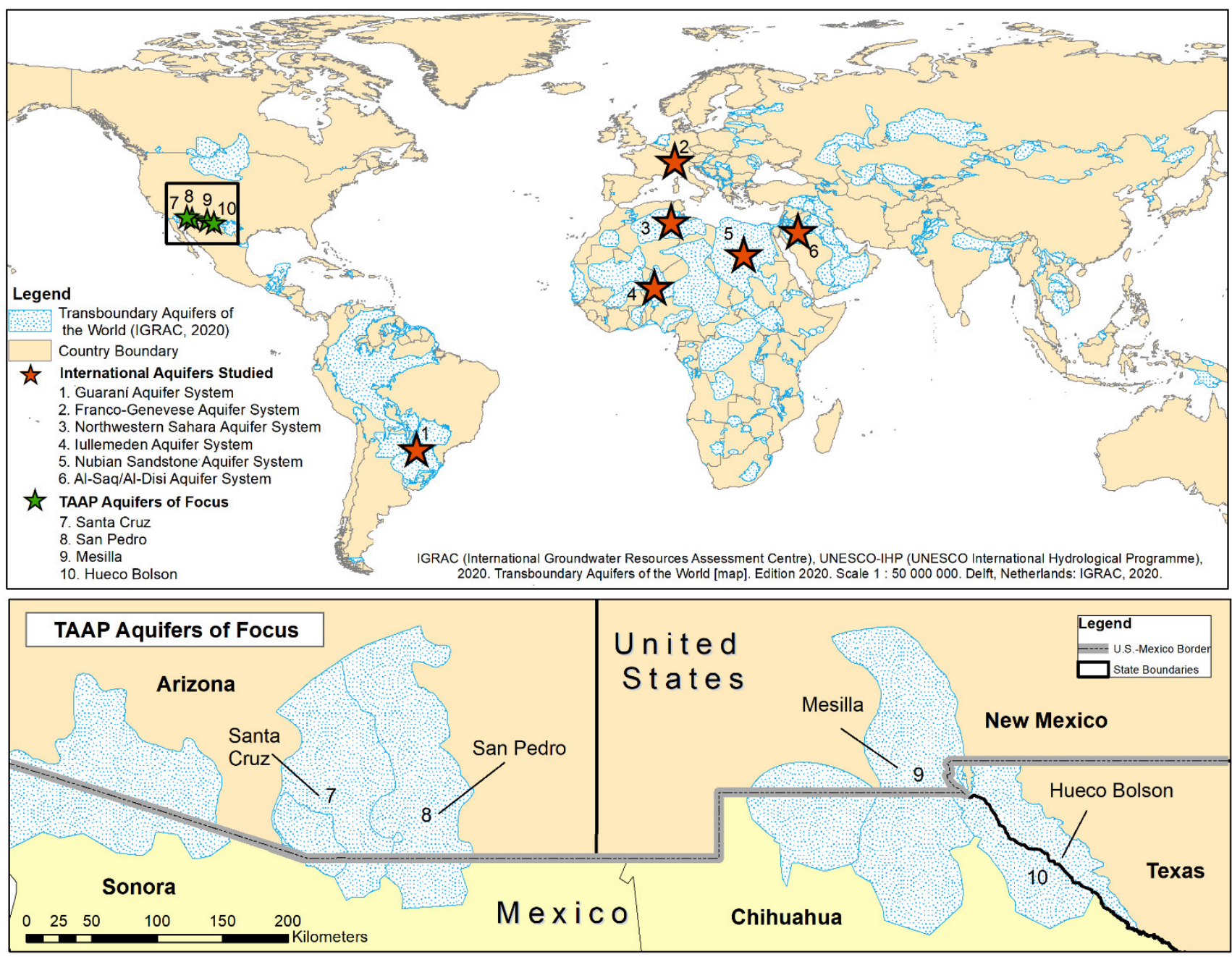

Figure 1. International Aquifers Studied and Transboundary Aquifer Assessment Program (TAAP) Aquifers of Focus, based on Transboundary Aquifers of the World [3].

Groundwater collaboration between the United States and Mexico is similar to other transboundary settings around the world. Efforts by the two countries to understand and manage groundwater resources have been scarce and sporadic [11]. The two countries have a surface water agreement, the 1944 Water Treaty Regarding the Utilization of Waters of the Colorado and Tijuana Rivers and of the Rio Grande (1944 Treaty); however, groundwater was left unmentioned. Only Minute 242 was approved in 1973 by the International Boundary and Water Commission (IBWC), one of many interpretations of the 1944 Treaty includes a provision that is relevant to groundwater. The IBWC is the international body that oversees the application of U.S.-Mexico treaties related to boundary demarcation, national ownership of waters, sanitation, water quality, and flood control in the border region [12]. Challenges in the management of groundwater resources in the U.S.-Mexico border region include rapid urbanization and industrialization, agricultural intensification, contamination of surface and groundwater resources, increase in surface and groundwater demands, and climate uncertainties [13-15]. These challenges indicate the need for binational transboundary collaboration to secure water for populations and the environment. 
Such a collaboration could take the form of a binational agreement for the management of groundwater resources. However, scholars have recognized that the assessment of shared aquifer systems is a necessary antecedent to the development of any groundwater management agreement [8,16-19]. For example, Kirstin I. Conti [18] indicated that scientific research is an enabling factor for groundwater cooperation, along with existing legal mechanisms, regional institutions, high institutional capacity, funding mechanisms, strong political will, previous water cooperation, and third-party involvement.

The Joint Report of the Principal Engineers Regarding the Joint Cooperative Process United States-Mexico for the Transboundary Aquifer Assessment Program (TAAP Cooperative Framework) [20], guides the joint effort between the United States and Mexico to improve the knowledge base of transboundary aquifers. The program began in 2006 with the Transboundary Aquifer Assessment Act (U.S. Public Law 109-448, TAA-Act). The TAA-Act authorized the United States Geological Survey (USGS) and the Water Resources Research Institutes (WRRIs) of Arizona, New Mexico, and Texas to work with Mexican counterparts on the development of transboundary aquifer assessments. The TAA-Act authorized U.S. involvement in binational studies of the Santa Cruz and San Pedro Aquifers, shared by the state of Arizona in the United States and the state of Sonora in Mexico, and the Mesilla and Hueco Bolson aquifers, shared by the states of Texas and New Mexico in the United States and the state of Chihuahua in Mexico (Figure 1). These priority aquifers were selected based on their proximity to highly populated areas, increasing groundwater demands, and water quality issues [21]. The binational TAAP was formally initiated in 2009 upon the signing of the TAAP Cooperative Framework by the principal engineers of the U.S. and Mexican sections of the IBWC. The two countries agreed upon the TAAP aquifers of focus consistent with the TAA-Act priority aquifers (Figure 1). According to the TAAP Cooperative Framework, either of the two countries can propose an aquifer of focus, but both countries must agree to develop a joint assessment.

The TAA-Act and the TAAP Cooperative Framework offer a foundation for collaboration to study shared groundwater resources through an effective partnership among federal agencies, academic institutions, and federally established water resources research institutes [21,22]. The TAAP can also be considered a climate and water adaptation initiative for the western U.S.-Mexico border [13], a transboundary regional initiative that has the potential to build adaptive capacity [15], an activity that can support decision-making processes related to groundwater management in each country [23], and a precedent for a binational partnership that can promote and implement a new binational aquifer assessment [9]. However, the relevance of the TAAP Cooperative Framework as a model mechanism for groundwater collaboration has not been fully addressed in the literature.

The TAAP Cooperative Framework is limited to assessment only, with four transboundary aquifers studied to date. The Map of Transboundary Aquifers of the World [3] includes 11 shared transboundary aquifers along the border between the United States and Mexico. Yet, a review of technical studies, reports, and publications on U.S.-Mexico transboundary aquifers suggest that at least 36 transboundary aquifers are shared by the two countries [24]. Clearly, additional study opportunities exist, and the activities undertaken by the TAAP can serve as the basis for assessment that goes beyond the current TAAP aquifers of focus and that can even guide future dialogue regarding groundwater governance and management [8]. The primary objective of the study is to determine whether the elements of the TAAP Cooperative Framework can serve as a model for others wishing to engage in transboundary aquifer assessment. Expert interviews and lessons learned from evaluating six existing international groundwater agreements helped to determine whether the objectives, framework/process, funding, principles, and communication arrangements of the TAAP Cooperative Framework can guide further groundwater cooperation.

\section{Materials and Methods}

The present work provides an assessment of the TAAP Cooperative Framework as a model for transboundary groundwater collaboration. To achieve this, we compared the 
elements of collaboration in the TAAP Cooperative Framework with the components of six transboundary groundwater collaboration agreements. The TAAP Cooperative Framework elements of collaboration were taken from the Joint Report of the Principal Engineers Regarding Joint Cooperative Process United States-Mexico for the Transboundary Aquifer Assessment Program (Cooperative Framework) [20]. These elements are presented in Table 1 and were used as a basis for comparison. Selected institutional governance agreements include the existing collaboration mechanisms for the following: (1) the Guaraní Aquifer System (GAS), (2) the Franco-Swiss Genevese Aquifer System, (3) the Northwestern Sahara Aquifer System, (4) the Iullemeden Aquifer System, (5) the Nubian Sandstone Aquifer System (NSAS), and (6) the Al-Saq/Al-Disi Aquifer System. These transboundary aquifers were selected because of their formal mechanisms of groundwater cooperation [17,18,25-27].

Table 1. TAAP Cooperative Framework elements of collaboration [20].

\section{Facilitate data exchange}

Objectives

Ensure the concurrence for binational aquifer assessment activities

Facilitate agreement on the aquifers, which will be evaluated jointly

Establish and coordinate binational technical advisory committees Establish an official repository for binational project reports

Either of the two countries can propose an aquifer to study

The International Boundary and Water Commission (IBWC) will coordinate with agencies from both countries to jointly define the scope of the assessment

Framework (Process) Binational technical groups will be established and coordinated by the IBWC The IBWC will facilitate concurrence of joint work plans

Whoever carries out the joint studies will update the binational technical groups with the project progress

The final reports that proceed from the joint studies will be published in English and Spanish and will be made available for publication once they have been approved within the IBWC framework

Funding

Each country will be responsible for any costs on projects conducted in its territory Either country may contribute to the costs of work done in the other country

Contributions will be distributed according to the process agreed on through the IBWC All projects and measures considered are subject to the availability of funds

Activities should be beneficial to both countries

Activities should be agreed on within the framework of the IBWC

Activities should respect the legal framework and jurisdictional requirements of each country

Principles No provision set forth in this agreement will limit what either country can do independently in its own territory

No part of this agreement may contravene what has been stipulated in the boundary and water treaties

The information generated from these projects is solely for the purpose of expanding knowledge

The IBWC will be an official repository of records

The final joint binational reports will be available to the public in each country and will be posted on the website of each section of the IBWC

Communication

Information obtained should be considered as official data and should be shared without any restrictions

Credit will be given to those who provide information

Stakeholder interviews implemented during 2019 and 2020 served to identify whether TAAP lessons can be generalized to other aquifers along the U.S.-Mexico border and elsewhere. The selection of participants was based on purposive sampling. This nonrandom technique does not need a set number of participants and interviewees are selected according to the qualities or knowledge they possess [28]. Interviewees consist of two IBWC experts (interview 1 and 2), two experts in political sciences (interview 3 and 4), and two researchers/scientists (interview 5 and 6). Selected interviewees were familiar with transboundary aquifer assessment and management and with the principles of the TAAP Cooperative Framework. Interview questions included: 
- According to your experience, what factors promote the successful groundwater collaboration between nations that share one or various aquifers?

- Do you think we can generalize the TAAP principles of collaboration to other aquifers within the U.S.-Mexico border?

- Do you think the TAAP Cooperative Framework can serve as a model for the assessment of other transboundary aquifers?

- Do you think the TAAP Cooperative Framework can serve as a basis for the development of future groundwater management agreements in the borderlands of the United States and Mexico?

\section{Results}

This section describes the history of transboundary groundwater collaboration around the world and the mechanisms of collaboration included in the analyzed groundwater agreements. We also present a comparison of the elements of the TAAP Cooperative Framework and the components of the six analyzed aquifer agreements. Expert interviews regarding the applicability of the TAAP Cooperative Framework to others contemplating transborder collaboration are also reported in this section.

\subsection{Transboundary Groundwater Resources and International Law}

Some of the international guidelines related to transboundary groundwater resources include the 1966 Helsinki Rules, the 1986 Seoul Rules, the 1997 UN Convention on the Law of the Non-Navigational Uses of Transboundary Watercourses (UN Watercourses Convention), the 1999 Convention on the Protection and Use of Transboundary Watercourses and International Lakes, the 2004 Berlin Rules, and the 2008 Draft Articles on the Law of Transboundary Aquifers [29-31]. These guidelines serve as a reference for groundwater management. However, only some of them recognize the connection between surface water and groundwater. For example, the UN Watercourses Convention addresses surface water and groundwater but fails to recognize confined aquifers [30]. The Convention on the Protection and Use of Transboundary Watercourses and International Lakes also fails to recognize confined transboundary aquifers even though it documents the importance of groundwater in the management of drainage basins [29].

The 2008 Draft Articles on the Law of Transboundary Aquifers (UN Draft Articles) do recognize confined aquifers $[1,32,33]$. Among many provisions, the UN Draft Articles include principles related to the sovereignty of the countries sharing an aquifer (Article 3), provisions for equitable and reasonable utilization of groundwater resources (Article 4), the obligation not to cause significant harm (Article 6), a general obligation to cooperate (Article 7), requirements for the regular exchange of data and information (Article 8), stipulations for the protection and preservation of ecosystems (Article 10), and guidelines for monitoring (Article 13). The United Nations General Assembly (UNGA), however, has not ratified the UN Draft Articles, though the item has been on its agenda several times in it will be again in 2022 [8]. Partly in response to this development in international law, other cases of groundwater collaboration mechanisms have been signed between countries [8]. For example, the Guaraní Aquifer System Agreement and the Bamako Declaration for the Iullemeden Aquifer System both refer to the UN Draft Articles [8,32]. Below, we present a summary of the mechanisms analyzed in this study.

\subsection{Transboundary Groundwater Collaboration around the World}

Diverse cultures, countries, and states connect to groundwater in a hydropolitical matrix that comprises the policies, social exchanges, discussions, and agreements between different nations [34]. Water allocation is a key component of water governance, and in transboundary settings, this process involves a variety of users competing in an unavoidable conflictual process [35]. The principle of equitable and reasonable utilization of water resources should guide groundwater allocation between different countries, yet there is no universal theory of justice to satisfy every water user [36]. 
According to the United Nations Sustainable Development Goals (SDG 6.5.2), "specific arrangements or agreements between co-riparian countries are a precondition to ensure long-term sustainable cooperation" $[37,38]$. In this section, we detail the six transboundary aquifers that have agreements or other arrangements established for groundwater collaboration. Table 2 presents a summary of the analyzed transboundary groundwater agreements, the countries involved, dates, and the purpose of each agreement, followed by an explanation of the main characteristics of each aquifer agreement. Focusing on the elements and history of each collaboration, we subsequently compare the agreements with the U.S.-Mexico TAAP Cooperative Framework.

Table 2. Transboundary Groundwater Agreements around the World.

\begin{tabular}{|c|c|c|c|c|}
\hline Aquifer System & Agreement & Countries Involved & Date(s) & $\begin{array}{l}\text { Agreement } \\
\text { Characteristics }\end{array}$ \\
\hline $\begin{array}{c}\text { Guaraní Aquifer System } \\
\text { (GAS) }\end{array}$ & $\begin{array}{l}\text { Guaraní Aquifer } \\
\text { Agreement }\end{array}$ & $\begin{array}{l}\text { Argentina Brazil } \\
\text { Paraguay Uruguay }\end{array}$ & $\begin{array}{c}\text { Signed in } 2010 \text { Ratified in } \\
2018\end{array}$ & $\begin{array}{l}\text { Promotes the sustainable } \\
\text { development of the } \\
\text { aquifer system } \\
\text { Solves issues arising } \\
\text { between countries } \\
\text { Aligned to the UN Draft } \\
\text { Articles }\end{array}$ \\
\hline $\begin{array}{c}\text { Franco-Swiss Genevese } \\
\text { Aquifer System }\end{array}$ & $\begin{array}{l}\text { Convention on the } \\
\text { Protection, Utilization, } \\
\text { Recharge, and Monitoring } \\
\text { of the Franco-Swiss } \\
\text { Genevese Aquifer }\end{array}$ & France Switzerland & $\begin{array}{c}\text { 1978-2008 } \\
\text { (New convention } \\
\text { established in 2008) }\end{array}$ & $\begin{array}{l}\text { Focused on groundwater } \\
\text { quality, quantity, and } \\
\text { artificial recharge } \\
\text { The only treaty to date } \\
\text { that allocated volumes of } \\
\text { water }\end{array}$ \\
\hline $\begin{array}{l}\text { Northwestern Sahara } \\
\text { Aquifer System }\end{array}$ & $\begin{array}{c}\text { The Permanent } \\
\text { Consultation Mechanism } \\
\text { for the Northwestern } \\
\text { Sahara Aquifer System }\end{array}$ & $\begin{array}{l}\text { Algeria } \\
\text { Libya } \\
\text { Tunisia }\end{array}$ & 2008 & $\begin{array}{c}\text { Developed a } \\
\text { hydrogeologic database } \\
\text { and model } \\
\text { Maintains an observation } \\
\text { network } \\
\text { Analyzes socioeconomic } \\
\text { activities } \\
\text { Develops joint studies } \\
\text { Formulates proposals for } \\
\text { optimization and } \\
\text { consultation mechanisms }\end{array}$ \\
\hline $\begin{array}{l}\text { Iullemeden Aquifer } \\
\text { System }\end{array}$ & Bamako Declaration & $\begin{array}{c}\text { Mali } \\
\text { Niger } \\
\text { Nigeria }\end{array}$ & 2009 & $\begin{array}{l}\text { Serves as a consultative } \\
\text { mechanism } \\
\text { Improves knowledge and } \\
\text { strenghtens regional } \\
\text { cooperation }\end{array}$ \\
\hline $\begin{array}{c}\text { Al-Saq/Al-Disi Aquifer } \\
\text { System }\end{array}$ & $\begin{array}{l}\text { Agreement between the } \\
\text { Government of the } \\
\text { Hashemite Kingdom of } \\
\text { Jordan and the } \\
\text { Government of the } \\
\text { Kingdom of Saudi Arabia } \\
\text { for the Management and } \\
\text { Utilization of the Ground } \\
\text { Waters in the } \\
\text { Al-Saq/Al-Disi Layer }\end{array}$ & $\begin{array}{l}\text { Jordan } \\
\text { Saudi Arabia }\end{array}$ & 2015 & $\begin{array}{c}\text { Restricts groundwater } \\
\text { extractions in protected } \\
\text { areas } \\
\text { Governs the digging of } \\
\text { observational wells } \\
\text { Controls pollution }\end{array}$ \\
\hline $\begin{array}{l}\text { Nubian Sandstone Aquifer } \\
\text { System }\end{array}$ & $\begin{array}{l}\text { Programme for the } \\
\text { Development of a } \\
\text { Regional Strategy for the } \\
\text { Utilization of the Nubian } \\
\text { Sandstone Aquifer System } \\
\text { and the Terms of } \\
\text { Reference for the } \\
\text { Monitoring and Exchange } \\
\text { of Groundwater } \\
\text { Information of the Nubian } \\
\text { Sandstone Aquifer System }\end{array}$ & $\begin{array}{l}\text { East Libya Egypt } \\
\text { Northeast Chad } \\
\text { North Sudan }\end{array}$ & 2000 & $\begin{array}{l}\text { Focuses on data exchange } \\
\text { and monitoring efforts }\end{array}$ \\
\hline
\end{tabular}




\subsubsection{Guaraní Aquifer System (GAS)}

Located across four South American countries, the GAS is one of the largest freshwater reservoirs in the world [26,39]. The GAS covers an area of 1,087,879 square kilometers $\left(\mathrm{km}^{2}\right)$, with the largest portion situated in Brazil, followed by Argentina, Paraguay, and Uruguay $[26,40]$. The breakdown of the reservoir's water resources usage is as follows: municipal water supply $(66 \%)$, industries $(16 \%)$, thermal tourism $(13 \%)$, and irrigation (5\%) [40]. The four countries sharing the aquifer are known for their collaboration regarding the La Plata River Basin [8] and have benefited from continuous research and development projects, such as the Environmental Protection and Sustainable Development of the Guaraní Aquifer System Project supported by the Organization of American States and the Common Market of the South [39,41].

The Guaraní Aquifer Agreement was signed in August 2010, but it was not ratified by all four countries until 2018. This document points to the principles described by the UN Draft Articles to promote the sustainable development of the aquifer system and to solve some of the issues that might arise in the aquifer countries. For instance, Articles 2 and 3 of the Guaraní Aquifer Agreement state that each of the parties has the sovereign right to promote the management, utilization, and monitoring of their portion of the aquifer system as long as they follow the principle of reasonable use. Data exchange and knowledge improvement are essential, as expressed in Articles 8 and 12. Finally, a commission oversees compliance by all parties with the principles of agreement [42]. Factors enabling transboundary collaboration among the countries that share the GAS include the existing regional institutions, funding mechanisms, high institutional capacity, previous water cooperation, scientific research, strong political will, and third-party involvement [18].

\subsubsection{Franco-Swiss Genevese Aquifer System}

The Franco-Swiss Genevese Aquifer System is shared by France and Switzerland and has an approximate areal extent of $19 \mathrm{~km}^{2}$ [27]. Ten wells on the Swiss side of the aquifer and four wells on the French side supply water to the Swiss Canton of Geneva and the neighboring French Territory (Haute-Savoie). The Convention on the Protection, Utilization, Recharge, and Monitoring of the Franco-Swiss Genevese Aquifer was established in 1978 after a dramatic decrease in groundwater levels associated with groundwater pumping [18,43].

The 1978 convention focused on groundwater quality, quantity, and artificial recharge, and it is the only treaty for transboundary aquifers that allocates specific volumes of water to the involved parties $[17,18,44]$. Despite the lack of provisions related to sovereignty rights, each of the parties has the right to make decisions around groundwater pumping, equipment, and abstraction margins [8,38]. Recharge from the Arve River is treated and channeled into the aquifer, helping to balance a seven million cubic meters $\left(\mathrm{Mm}^{3}\right)$ per year overdraft $[43,45]$. A joint commission oversees the preparation of groundwater management plans, the monitoring of groundwater, the efforts to gain approval for new infrastructures, and the verification of construction and operation costs of artificial recharge facilities [17]. The commission consists of six members, at least four of whom are experts in water-related issues [17].

When the 1978 convention expired, a new convention came into effect on 1 January, 2008 [46]. This new agreement includes the French communities of Annemasse, the rural districts of Genevois, and the municipality of Viry. The fact that the 1978 convention did not include participation from the federal government of either country adds a local dimension to the arrangement that was essential for the success of the agreement [25]. Technical and scientific studies were also crucial for resolving the overexploitation problems, and they served as the basis for collaboration efforts [43].

\subsubsection{Northwestern Sahara Aquifer System}

Shared by Algeria, Libya, and Tunisia, the Northwestern Sahara Aquifer System has an areal extent of 1,019,000 $\mathrm{km}^{2}$. The Permanent Consultation Mechanism for the Northwestern Sahara Aquifer System was signed in July 2008 by the three countries' 
representatives [26]. The consultation mechanism is composed of a steering committee and a scientific committee [47]. The many goals of the agreement include (1) the development of a hydrogeologic database and groundwater flow model; (2) the setup of an observation network to process, analyze, and validate data; (3) the analysis of the socioeconomic activities of the region; (4) the coordination for the development of joint studies, and (5) the formulation of proposals for optimization and consultation mechanisms [48].

Collaboration among the countries sharing the aquifer has lasted at least 45 years, with activities designed to improve scientific knowledge about the aquifer. Features of collaboration for the Northwestern Sahara Aquifer System include political will, funding, and available institutions, such as the Observatoire du Sahara et du Sahel (Sahara and Sahel Observatory-OSS) [18]. Thus far, collaborative efforts have focused on scientific studies of the aquifer, and transboundary groundwater management has not yet occurred.

\subsubsection{Iullemeden Aquifer System}

The Sahel region aquifers in West Africa include the Iullemeden-Taoudeni/Tanezrouft Aquifer System. Shared by Mali, Niger, and Nigeria, the Iullemeden Aquifer System has an areal extent of $525,000 \mathrm{~km}^{2}$. The cooperative and financing mechanisms of the region, along with their regional institutions, have been shaped by 20 years of collaboration that has led to the development of two agreements: (1) the Protocol on Cooperation of the Utilization of the Niger River, signed by Mali and Niger in 1988, and (2) the Joint Commission for Cooperation on Equitable Sharing for Development, Conservation, and Utilization of the Common Water Resources, signed by Niger and Nigeria in 1990 [18]. Later, the Bamako Declaration for the Iullemeden Aquifer, which is a Memorandum of Understanding (MOU) that encourages collaboration between the three countries, was signed by Mali, Niger, and Nigeria in 2009. The MOU recognizes the importance of water resources for alleviating poverty, acknowledges the rights and duties of the countries sharing the aquifer, appreciates the achievements of the improvement of the scientific knowledge associated with the aquifer, and highlights the importance of cooperative management of the Iullemeden Aquifer System in improving the management of shared groundwater resources [49].

Additionally, the countries commit to adopting the principles of the equitable and reasonable use of shared groundwater resources, exchanging information, giving prior notification of planned work, and adopting environmental protection regulations [32]. This collaborative effort evolved into the development of another MOU in 2014, this time, among the countries of Algeria, Benin, Burkina Faso, Mali, Mauritania, Niger, and Nigeria, for the establishment of a Consultative Mechanism for the Iullemeden and Taoudeni/Tanezrouft Aquifer Systems (ITAS). This MOU, however, is not yet in effect, pending the signatures of three of the parties [50]. The consultative mechanisms of the ITAS demonstrate the readiness to develop management strategies, though the agreement has not evolved into additional management actions $[1,26]$.

\subsubsection{Nubian Sandstone Aquifer System (NSAS)}

The Nubian Sandstone Aquifer System consists of a series of laterally and/or vertically interconnected aquifers that extend across more than 2,000,000 $\mathrm{km}^{2}$ in East Libya, Egypt, Northeast Chad, and North Sudan [17]. The formal agreements ratified by the countries sharing the aquifer include (1) the Programme for the Development of a Regional Strategy for the Utilization of the Nubian Sandstone Aquifer System and (2) the Terms of Reference for the Monitoring and Exchange of Groundwater Information of the Nubian Sandstone Aquifer System, both signed in October 2000 [47]. The NSAS projects, which are considered initial stages of groundwater collaboration, are widely supported by donors and the scientific community [51].

Though these agreements are relatively recent, the collaboration between Libya and Egypt dates back to 1991, when the Joint Authority of the Nubian Sandstone Aquifer System (JASD-NSAS) was established [47]. The first countries to join were Libya and 
Egypt, with Sudan and Chad following in 1996 and 1999, respectively [52]. The information shared under the NSAS agreement includes yearly groundwater extractions, electrical conductivity measurements, chemical analysis, and water-level measurements [48]. In 2012, the Regional Strategic Action Program for the Nubian Sandstone Aquifer System was negotiated through the Action Programme for the Integrated Management of the Shared Nubian Aquifer, which included guidance for future groundwater management agreements [18,53]. The JASD-NSAS has a regional expert group, with offices in each of the countries sharing the aquifer, as well as specific units for public relations, follow-up, finance, technical affairs, information, and administration.

\subsubsection{Al-Saq/Al-Disi Aquifer System}

The Al-Saq/Al-Disi Aquifer is a reservoir of fossil water shared by Jordan (Al-Saq Aquifer) and Saudi Arabia (Al-Disi Aquifer). Groundwater recharge in the region is minimal, and the two countries seem to be involved in a pumping race that might lead to the inevitable depletion of the groundwater resource [54]. The Agreement between the Government of the Hashemite Kingdom of Jordan and the Government of the Kingdom of Saudi Arabia for the Management and Utilization of the Ground Waters in the Al-Saq/AlDisi Layer was signed on 4 April, 2015. The Al-Saq/Al-Disi Aquifer area covered by the agreement has an area extent of $308,000 \mathrm{~km}^{2}$ [55].

The agreement restricts groundwater extractions in protected areas, encourages the drilling of observation wells, and includes pollution control statements. The agreement authorizes the drilling of wells in the management area between Jordan and Saudi Arabia but limits water usage for municipal purposes. A joint Saudi/Jordanian technical committee formed by five members from each country is responsible for supervising the implementation of the terms of the agreement, monitoring groundwater quality and quantity, and exchanging data and information between the involved parties. The agreement calls for members of the joint committee to have one meeting every six months. However, it was reported that as of 2018, the committee has never met [50]. According to the agreement, data exchange with a third party is not allowed unless approved by the two countries. Activities by the joint committee can be completed with the help of experts, technicians, officials, and citizens from the two countries. The agreement will be reviewed every 25 years, and any amendment will be studied by the joint committee and referred to the appropriate authorities. In this case, informal political meetings contributed to the development and signing of the MOU in 2015 [36]. However, the countries have not truly reached a bilateral treaty over the use of their shared groundwater [36].

\subsection{Transboundary Groundwater Collaboration between the United States and Mexico}

The allocation of shared surface water resources between the United States and Mexico is governed by the 1944 Water Treaty Regarding the Utilization of Waters of the Colorado and Tijuana Rivers and of the Rio Grande (1944 Treaty). The treaty, however, leaves groundwater unmentioned. The IBWC, established in 1889, is the international body that oversees the application of U.S.-Mexico treaties regarding boundary demarcation, water resources, and sanitation in the border region [12]. It received the name of the International Boundary Commission (IBC) before the signing of the 1944 Treaty.

The IBWC is composed of the U.S. and a Mexican Section. The U.S. Section is housed in the U.S. Department of State and has headquarters in El Paso, Texas. The Mexican Section is operated by the Mexican Ministry of Foreign Affairs, with headquarters in Ciudad Juarez, Chihuahua. To implement international treaty provisions, the IBWC requires specific agreements, which have been recorded in the form of Minutes and date back to 1889. A key pillar of the 1944 Treaty is that it allows for interpretations or modifications (Minutes) to adapt to new challenges that emerge between the two countries [56]. These Minutes are considered extensions and applications of the treaty [56]. To date, 324 Minutes act as binding obligations between the United States and Mexico, but only Minute 242 for the "Permanent and Definitive Solution to the International Problem of the Salinity 
of the Colorado River" specifically includes groundwater management provisions [57]. Resolution 5 of Minute 242 establishes that "pending the conclusion by the Governments of the United States and Mexico of a comprehensive agreement on groundwater in the border areas, each country shall limit pumping of groundwater in its territory within eight kilometers of the Arizona-Sonora boundary near San Luis to 197,358,000 cubic meters annually" [57]. Minute 323, "Extension of Cooperative Measures and Adoption of a Binational Water Scarcity Contingency Plan in the Colorado River Basin," is a relevant example of cooperation for many reasons, including the assessment of desalination impacts [58]. While this Minute does not consider groundwater, it does consider a binational assessment effort within the context of the IBWC and the 1944 Treaty.

Aside from the 1944 Treaty framework, the Bellagio Draft Treaty represents another fine example of the progress being made toward the understanding and management of the U.S.-Mexico transboundary aquifers [16]. The treaty suggests a structure by which the United States and Mexico can work cooperatively, describing the development of a bilateral institution that will allow the United States and Mexico to jointly study and manage their shared groundwater resources [59]. Moreover, it emphasizes the importance of knowledge improvement for the development of joint agreements and the management of groundwater resources. Another collaborative effort between the United States and Mexico, the MOU between Ciudad Juárez Water Utilities and El Paso Water Utilities promotes the exchange of information and the development of binational studies in the region $[18,47]$. This surface-water and groundwater assessment effort represents a local approach arranged by interested communities [11], indicating the presence of different paths toward scientific groundwater collaboration on a local or regional scale.

Finally, the TAAP Cooperative Framework represents another mechanism of binational collaboration between the United States and Mexico. The knowledge-improvement goals included in the TAAP Cooperative Framework coincide with the data-collection efforts and assessment of shared water resources described in the Bellagio Draft Treaty of 1989. The TAAP Cooperative Framework is described below.

\subsection{The United States-Mexico Transboundary Aquifer Assessment Program}

Recognizing the interest of the United States and Mexico to understand their shared aquifers, and with U.S. Public Law $109-448$ as a precedent, the Principal Engineers of the U.S. and Mexican sections of the IBWC signed the Joint Cooperative Process United States-Mexico for the Transboundary Aquifer Assessment Program (TAAP Cooperative Framework) in August 2009. While some scholars argue that TAAP marginalizes issues such as water rights and management [60], others have contended that improving understanding of the U.S.-Mexico transboundary aquifers, which is the objective of the TAAP Cooperative Framework, is a necessary first step toward a binational groundwater management agreement between the United States and Mexico [19].

The TAAP Cooperative Framework promotes the development of binational technical groups to evaluate shared aquifers, advocates for knowledge improvement and data exchange, and states that each country has an obligation to cooperate [24]. It is worth noting that these principles correspond to UN Draft Articles 7 and 8, "General Obligation to Cooperate" and "Regular Exchange of Data and Information" [19]. Additionally, TAAP principle 4 considers the sovereignty of each nation by stating, "no provision set forth [in this agreement] will limit what either country can do independently in its own territory." This principle is consistent with UN Draft Article 3, "Sovereignty of Aquifer States" or countries that share the aquifer. UN Draft Article 13, regarding monitoring, is also consistent with the overall TAAP objective of improving knowledge of transboundary aquifer conditions.

Accomplishments of the TAAP include the development of the Mesilla Valley Hydrologic Model; the completion of the Binational Study of the Transboundary San Pedro Aquifer; the establishment of research projects in Texas, New Mexico, Arizona, Sonora, and Chihuahua; the output of numerous publications and conference presentations; and 
fieldwork in the U.S. and Mexican portions of the priority aquifers [61]. Additionally, over 50 binational meetings have taken place, many of them were between the technical workgroups established pursuant to the Cooperative Framework.

An existent legal mechanism for collaboration, regional institutions, funding mechanisms, high institutional capacity, previous water cooperation, and scientific research are some of the enabling mechanisms for groundwater collaboration that are present in the TAAP collaboration and that might facilitate future groundwater collaboration between the two countries.

3.4.1. Common Elements of Collaboration between the TAAP Cooperative Framework and International Aquifer Agreements

A comparison of the elements of the TAAP Cooperative Framework and the components of the six international groundwater agreements is presented in Table 3. Five items were particularly relevant as common features of collaboration: (1) the presence of data exchange provisions, which was true for all the agreements but the Al-Saq/Al-Disi Aquifer System; (2) the concurrence for binational aquifer assessment, agreed on and implemented by all the countries sharing an aquifer; (3) the establishment of technical advisory committees, which occurred in all of the countries; (4) the presence of technical groups, discussed in every agreement except the Bamako Declaration, and; (5) respect for the legal framework and jurisdictional requirements of each country, which was inferred from the content of each of the agreements and which apply to all of the analyzed aquifers.

Table 3. Common elements of collaboration between transboundary groundwater agreements $(\boldsymbol{V}=$ Component present in the agreement, $\boldsymbol{X}=$ component absent in the agreement, ${ }^{*}=$ inferred present component, ? = unspecified component, not shown in the agreement and cannot be inferred from additional content).

\begin{tabular}{|c|c|c|c|c|c|c|c|c|}
\hline & Elements of Collaboration & TAAP & GAS & $\begin{array}{l}\text { Franco-Swiss } \\
\text { Genevese }\end{array}$ & $\begin{array}{l}\text { Northwestern } \\
\text { Saharan }\end{array}$ & Iullemeden & NAS & $\begin{array}{l}\text { Al-Saq/ } \\
\text { Al-Disi }\end{array}$ \\
\hline \multirow{4}{*}{ Objectives } & \multirow{2}{*}{$\begin{array}{c}\text { Exchange data } \\
\text { Concur on binational aquifer assessment } \\
\text { activities }\end{array}$} & $\checkmark$ & $\checkmark$ & $\boldsymbol{\nu}$ & $\boldsymbol{\sim}$ & $\checkmark$ & $\boldsymbol{v}$ & $x$ \\
\hline & & $v$ & $v$ & $\nu$ & $\checkmark$ & $v$ & 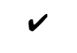 & $\checkmark$ \\
\hline & $\begin{array}{l}\text { Establish and coordinate technical } \\
\text { advisory committees }\end{array}$ & $\boldsymbol{V}$ & $\boldsymbol{v}$ & $\boldsymbol{v}$ & $\boldsymbol{v}$ & $\boldsymbol{V}^{*}$ & $\boldsymbol{v}$ & $\boldsymbol{v}$ \\
\hline & $\begin{array}{l}\text { Establish an official repository for } \\
\text { binational project reports }\end{array}$ & $\checkmark$ & $?$ & $?$ & $\boldsymbol{v}$ & $?$ & $?$ & $x$ \\
\hline \multirow{3}{*}{$\begin{array}{l}\text { Framework } \\
\text { (Process) }\end{array}$} & Establish technical groups & $\boldsymbol{v}$ & $\boldsymbol{v}$ & $\checkmark$ & $\boldsymbol{V}$ & $\mathrm{X}$ & $\boldsymbol{V}$ & $\boldsymbol{v}$ \\
\hline & Develop project progress reports & $\checkmark$ & $\checkmark$ & $\checkmark$ & $\boldsymbol{v}$ & $?$ & $\boldsymbol{v}$ & $\checkmark$ \\
\hline & Publish final reports & $\checkmark$ & $?$ & $\boldsymbol{v}$ & $\boldsymbol{v}$ & $?$ & $\checkmark$ & $x$ \\
\hline Funding & Arranged between the parties & $\checkmark$ & $?$ & $\checkmark$ & $\boldsymbol{\nu}$ & $?$ & $?$ & $?$ \\
\hline \multirow{6}{*}{ Principles } & $\begin{array}{l}\text { Activities should be beneficial to both } \\
\text { countries }\end{array}$ & $\checkmark$ & $\boldsymbol{V}^{*}$ & $\boldsymbol{V} *$ & $\boldsymbol{V}^{*}$ & $\boldsymbol{V}^{*}$ & $\boldsymbol{V}^{*}$ & $\boldsymbol{V}^{*}$ \\
\hline & $\begin{array}{c}\text { Activities should be agreed on within } \\
\text { the framework of the coordinating } \\
\text { agency } \\
\text { Activities should respect the legal }\end{array}$ & $\checkmark$ & $?$ & $?$ & $?$ & $?$ & $?$ & $?$ \\
\hline & $\begin{array}{l}\text { framework and jurisdictional } \\
\text { requirements of each country }\end{array}$ & $\checkmark$ & $\checkmark$ & $\checkmark$ & $\boldsymbol{V}$ & $\checkmark$ & $\checkmark$ & $\checkmark$ \\
\hline & $\begin{array}{l}\text { No provision set forth in this agreement } \\
\text { will limit what either country can do } \\
\text { independently in its own territory } \\
\text { No part of this agreement may }\end{array}$ & $\checkmark$ & $\boldsymbol{V}$ & $\boldsymbol{V}$ & $\checkmark$ & $?$ & $\boldsymbol{V}$ & $x$ \\
\hline & $\begin{array}{l}\text { contravene what has been stipulated in } \\
\text { the Boundary and Water Treaties }\end{array}$ & $\checkmark$ & $\boldsymbol{V}$ & $\boldsymbol{V}$ & $\boldsymbol{V}$ & $?$ & $\checkmark$ & $\checkmark$ \\
\hline & $\begin{array}{l}\text { The information generated from these } \\
\text { projects is solely for the purpose of } \\
\text { expanding knowledge }\end{array}$ & $\checkmark$ & $x$ & $x$ & $\checkmark$ & $x$ & $\checkmark$ & $x$ \\
\hline \multirow{4}{*}{ Communication } & $\begin{array}{l}\text { An official repository of records will be } \\
\text { present }\end{array}$ & $\checkmark$ & $?$ & $?$ & $\checkmark$ & $?$ & $?$ & $x$ \\
\hline & $\begin{array}{l}\text { Reports will be available to the public in } \\
\text { each country }\end{array}$ & $\checkmark$ & $?$ & $\checkmark$ & $\checkmark$ & $?$ & $\boldsymbol{v}$ & $x$ \\
\hline & $\begin{array}{l}\text { Information obtained will be considered } \\
\text { official data and will be shared without } \\
\text { any restrictions }\end{array}$ & $\checkmark$ & $?$ & $\checkmark$ & $\checkmark$ & $?$ & $\checkmark$ & $x$ \\
\hline & $\begin{array}{l}\text { Credit will be given to those who } \\
\text { provide information }\end{array}$ & $\boldsymbol{v}$ & $\boldsymbol{V}^{*}$ & $\boldsymbol{V} *$ & $\boldsymbol{V}^{*}$ & $\boldsymbol{V}^{*}$ & $\boldsymbol{V}^{*}$ & $?$ \\
\hline
\end{tabular}


These features of collaboration, present in all of the agreements except the Al-Saq/AlDisi Aquifer System and the Iullemeden Aquifer, are in alignment with the main objective of the TAAP Cooperative Framework, which is to improve knowledge of transboundary aquifers. These features also demonstrate that groundwater assessment is necessary for managing transboundary aquifers. A notable difference between the agreements and the TAAP Cooperative Framework is the use of information. While the data generated through the TAAP serve only to improve knowledge, as do the data generated for the NSAS and the NSA, the information and monitoring outcomes from the GAS, Franco-Swiss Genevese Aquifer, Al-Saq/Al-Disi Aquifer System, and Iullemeden Aquifer can be used for decision-making purposes with respect to groundwater management.

Another difference between the agreements and the TAAP Cooperative Framework is the availability of aquifer assessment data to the public, which is not discussed by or does not apply to the rest of the transboundary aquifers. The IBWC is the official repository of the available studies, which are published in both English and Spanish through the organization's official website. The financial arrangements, as described in the TAAP Cooperative Framework, were rather uncommon, being present in the Franco-Swiss Genevese and the Northwestern Saharan Aquifer agreements only.

\subsubsection{Expert Interviews on U.S.-Mexico Transboundary Groundwaters}

Expert interviews on transboundary groundwater served to determine whether the TAAP principles of agreement could guide transboundary aquifer assessment in areas that have not entered into formal agreements for binational collaborative studies, ultimately leading to the development of groundwater management arrangements or agreements (Table 4).

Table 4. Summary of expert interview responses.

\begin{tabular}{|c|c|c|c|c|c|c|}
\hline Question & Interviewee 1 & Interviewee 2 & Interviewee 3 & Interviewee 4 & Interviewee 5 & Interviewee 6 \\
\hline $\begin{array}{l}\text { According to } \\
\text { your experience, } \\
\text { what factors } \\
\text { promote the } \\
\text { successful } \\
\text { groundwater } \\
\text { collaboration } \\
\text { between nations } \\
\text { that share one or } \\
\text { various aquifers? }\end{array}$ & $\begin{array}{c}\text {-Interest } \\
\text {-Compliance with } \\
\text { existing } \\
\text { agreements } \\
\text {-Respect for } \\
\text { cultural } \\
\text { differences } \\
\text {-Consideration for } \\
\text { institutional } \\
\text { asymmetries }\end{array}$ & $\begin{array}{l}\text {-Friendly } \\
\text { relations between } \\
\text { countries } \\
\text {-Pre-existing } \\
\text { framework for } \\
\text { collaboration }\end{array}$ & $\begin{array}{c}\text {-Pre-existing } \\
\text { institutional } \\
\text { framework } \\
\text {-Data-sharing } \\
\text { mechanisms } \\
\text {-Trust } \\
\text {-Interest } \\
\text {-Funding }\end{array}$ & $\begin{array}{c}\text {-Trust } \\
\text {-Considering } \\
\text { imbalances } \\
\text { between } \\
\text { countries } \\
\text { - Processes that } \\
\text { promote trust, } \\
\text { e.g., data sharing } \\
\text { and prior } \\
\text { notification } \\
\text {-Avoiding } \\
\text { water-right } \\
\text { discussions in the } \\
\text { initial stages }\end{array}$ & $\begin{array}{c} \\
\text {-Trust } \\
\text {-Common } \\
\text { issues/problems } \\
\text {-People-not } \\
\text { institutions- } \\
\text { promoting } \\
\text { cooperation }\end{array}$ & $\begin{array}{l}\text {-Local } \\
\text { agreements } \\
\text {-Avoiding } \\
\text { water-right } \\
\text { discussions } \\
\text {-Focusing on } \\
\text { water quality }\end{array}$ \\
\hline $\begin{array}{l}\text { Do you think we } \\
\text { can generalize the } \\
\text { TAAP principles } \\
\text { of collaboration } \\
\text { and apply them } \\
\text { to other aquifers } \\
\text { within the } \\
\text { U.S.-Mexico } \\
\text { border? } \\
\text { Do you think the } \\
\text { TAAP } \\
\text { Cooperative } \\
\text { Framework can } \\
\text { serve as a model } \\
\text { for the } \\
\text { assessment of } \\
\text { other } \\
\text { transboundary } \\
\text { aquifers? }\end{array}$ & $\begin{array}{c}\text {-General } \\
\text { principles can be } \\
\text { utilized } \\
\text {-Take into account } \\
\text { the uniqueness of } \\
\text { each aquifer } \\
\text { system }\end{array}$ & $\begin{array}{l}\text {-Principles can } \\
\text { help other } \\
\text { countries deal } \\
\text { with the use of } \\
\text { shared } \\
\text { groundwater } \\
\text { resources } \\
\text {-Absolute } \\
\text { commitment is } \\
\text { needed between } \\
\text { countries }\end{array}$ & $\begin{array}{c}\text {-Important model } \\
\text { to consider in } \\
\text { countries with or } \\
\text { without } \\
\text { pre-existing } \\
\text { frameworks for } \\
\text { collaboration } \\
\text {-Depends on the } \\
\text { circumstances } \\
\text {-Require } \\
\text { higher-level } \\
\text { discussions } \\
\text {-Partnerships } \\
\text { among } \\
\text { universities, } \\
\text { federal agencies, } \\
\text { and coordinating } \\
\text { agencies provide } \\
\text { a favorable model }\end{array}$ & $\begin{array}{l}\text {-Follow the basic } \\
\text { rules of } \\
\text { cooperation and } \\
\text { apply them to the } \\
\text { specific needs of } \\
\text { each aquifer }\end{array}$ & - & $\begin{array}{l}\text {-Elements are } \\
\text { good but worked } \\
\text { due to the } \\
\text { leadership of } \\
\text { specific members } \\
\text {-Does not have } \\
\text { federal strength } \\
\text {-Political } \\
\text { sensitivity limits } \\
\text { data sharing } \\
\text {-Formality of } \\
\text { relations slows } \\
\text { down } \\
\text { collaboration }\end{array}$ \\
\hline
\end{tabular}


Table 4. Cont.

\begin{tabular}{|c|c|c|c|c|c|c|}
\hline Question & Interviewee 1 & Interviewee 2 & Interviewee 3 & Interviewee 4 & Interviewee 5 & Interviewee 6 \\
\hline $\begin{array}{l}\text { Do you think the } \\
\text { TAAP } \\
\text { Cooperative } \\
\text { Framework can } \\
\text { serve as a basis } \\
\text { for the } \\
\text { development of } \\
\text { future } \\
\text { groundwater } \\
\text { management } \\
\text { agreements in the } \\
\text { borderlands of } \\
\text { the United States } \\
\text { and Mexico? }\end{array}$ & $\begin{array}{l}\text {-Principles can } \\
\text { serve as a } \\
\text { foundation } \\
\text {-There has to be a } \\
\text { reason/interest } \\
\text { that drives the } \\
\text { development of a } \\
\text { groundwater } \\
\text { management } \\
\text { agreement }\end{array}$ & $\begin{array}{c}\text {-Smaller, } \\
\text { localized } \\
\text { agreements are } \\
\text { needed } \\
\text {-States should be } \\
\text { involved }\end{array}$ & $\begin{array}{c}\text {-A framework for } \\
\text { talking about } \\
\text { groundwater } \\
\text { management is } \\
\text { needed }\end{array}$ & $\begin{array}{c}\text {-A generic } \\
\text { framework for } \\
\text { collaboration is } \\
\text { needed } \\
\text {-You can } \\
\text { implement a } \\
\text { framework for } \\
\text { the whole border } \\
\text { stating that each } \\
\text { aquifer must have } \\
\text { its own regime }\end{array}$ & $\begin{array}{l}\text {-I don't think so } \\
\text {-Water } \\
\text { management } \\
\text { differs greatly } \\
\text { between the } \\
\text { borderlands }\end{array}$ & $\begin{array}{l}\text {-Not as it stands } \\
\text { right now } \\
\text {-Does not help to } \\
\text { plan, manage, or } \\
\text { learn about the } \\
\text { border } \\
\text {-It is limited to } \\
\text { only four aquifers }\end{array}$ \\
\hline
\end{tabular}

Interviewees reported that the TAAP principles are general enough to be used as a guide to promoting additional groundwater collaboration for the assessment of other transboundary aquifers in the United States and Mexico. This can be supported by a statement included within the TAAP Cooperative Framework (framework/processes): "Either of the two countries can propose an aquifer to study. Within the IBWC framework, it will be determined whether the proposal is in common interest and, as appropriate, a joint program developed." However, the commitment of the involved countries must be "absolute"; i.e., the time frame, funding, and political support for the analysis should be established between the collaborating parties. Participants also commented that because the TAAP effort involves partnerships among universities, federal agencies, and coordinating agencies, it provides a favorable model for collaboration. Nevertheless, its application would depend on the circumstances of each partner country and also on the leadership of the involved members. Historic or high levels of distrust between the two countries may interfere with the process of collaboration, while a pre-existing foundation, as demonstrated by the 1944 Treaty and the IBWC Framework in the case of Mexico, has facilitated collaboration. On the other hand, it was also expressed that even though the elements of the TAAP Cooperative Framework are effective, it lacks a binding capacity and federal and institutional support from both the United States and Mexico, a fact that sometimes hinders cooperation between the two nations.

Regarding the development of transboundary groundwater management agreements between the United States and Mexico, interviewees stated that the uniqueness of each aquifer system might require the development of aquifer-specific agreements. It was also expressed that the TAAP Cooperative Framework, as it stands right now, cannot serve as the foundation for groundwater management agreements due to the differences in water management between the United States and Mexico. An alternative proposed during the interview process was the possible development of a regional agreement for the use of groundwater resources in the border region. Such an agreement could employ principles of the TAAP Cooperative Framework, and it should be consistent with the UN Draft Articles and existing international groundwater agreements, as well. According to the interviews, the case of aquifer-specific agreements will require the direct involvement of each of the individual states, due to the decentralized way in which water resources are managed in the United States. Each state within U.S. territory has different needs, goals, funds, and management schemes; therefore, each state must play an active role in the development of an agreement.

Interviewees expressed that trust is a key factor in successful groundwater collaboration and that data sharing processes can improve trust between different countries. The interest between involved parties and common issues can also promote collaboration. Respect for cultural differences, institutional asymmetries, and economic imbalance is essential. Finally, additional indicators of successful groundwater collaboration include 
the presence of a pre-existing institutional framework and the countries' compliance with pre-existing agreements.

\subsubsection{The TAAP Cooperative Framework as a Model for Groundwater Collaboration}

The TAAP is a binational scientific effort that enabled groundwater data exchange and harmonization, knowledge improvement of the TAAP aquifers of focus, and trust-building among the federal agencies, academic institutions, and water resources research institutes that collaborated in the program. It was enabled by a governance approach, the Joint Report of the Principal Engineers Regarding Joint Cooperative Process United States-Mexico for the Transboundary Aquifer Assessment Program of 2009, and, for the United States, the TAA-Act of 2006 (Figure 2). The TAAP history of collaboration exhibits six out of eight enabling factors for groundwater collaboration described in the current literature [18]: (1) a strong regional institution like the IBWC (U.S. and Mexican Section); (2) existing legal mechanisms, such as the 1944 Treaty and the IBWC Minutes; (3) previous water collaboration for solving water-related issues; (4) third-party involvement from entities that do not belong to the government of each country, such as academic institutions; (5) scientific research on transboundary aquifers, and; (6) funding mechanisms (Figure 2). Although the two remaining features, high institutional capacity, and strong political will are not fully present in the TAAP, they are not absent either. Strong political will is identified when high-ranking officials prioritize transboundary water management [18]. However, the facilitation of diplomatic events and meetings like the ones hosted by the IBWC and TAAP can be considered an early sign for the strengthening of political will. The monitoring and modeling efforts that are present in the TAAP can also be considered factors that strengthen institutional capacity.

The TAAP represents a pre-existing institutional arrangement that promotes trust development between the United States and Mexico, in addition to the development of groundwater assessment studies within the aquifers of focus. These outcomes position the two countries to move forward in one of two ways: (1) implement additional assessment within the transboundary aquifers shared by the United States and Mexico, or (2) initiate dialogue toward the need of developing groundwater management mechanisms for the two countries. While a dialog is needed between the United States and Mexico to determine the need for a possible groundwater management agreement and the scale of the agreement itself, the importance of considering the unique physical, cultural, institutional, and economic characteristics surrounding specific aquifers is essential, as expressed during the expert interviews.

The analysis of common elements of collaboration between existing groundwater cooperation mechanisms and the TAAP indicates that the program itself, which is guided by the TAAP Cooperative Framework, has laid the groundwork for the development of additional aquifer assessment studies along the U.S.-Mexico border. The principles contained within the framework, which already include the majority of the elements described in pre-existing aquifer agreements, allow the two countries to continue studying additional aquifers and help to build trust between the involved parties (Figure 2). Moreover, the TAAP encompasses tenets such as communication and funding principles not previously mentioned in other aquifer agreements. These statements support the fact that the TAAP Cooperative Framework can be used as a model for transborder groundwater collaboration for the assessment of transboundary aquifers between the United States and Mexico and around the world. 


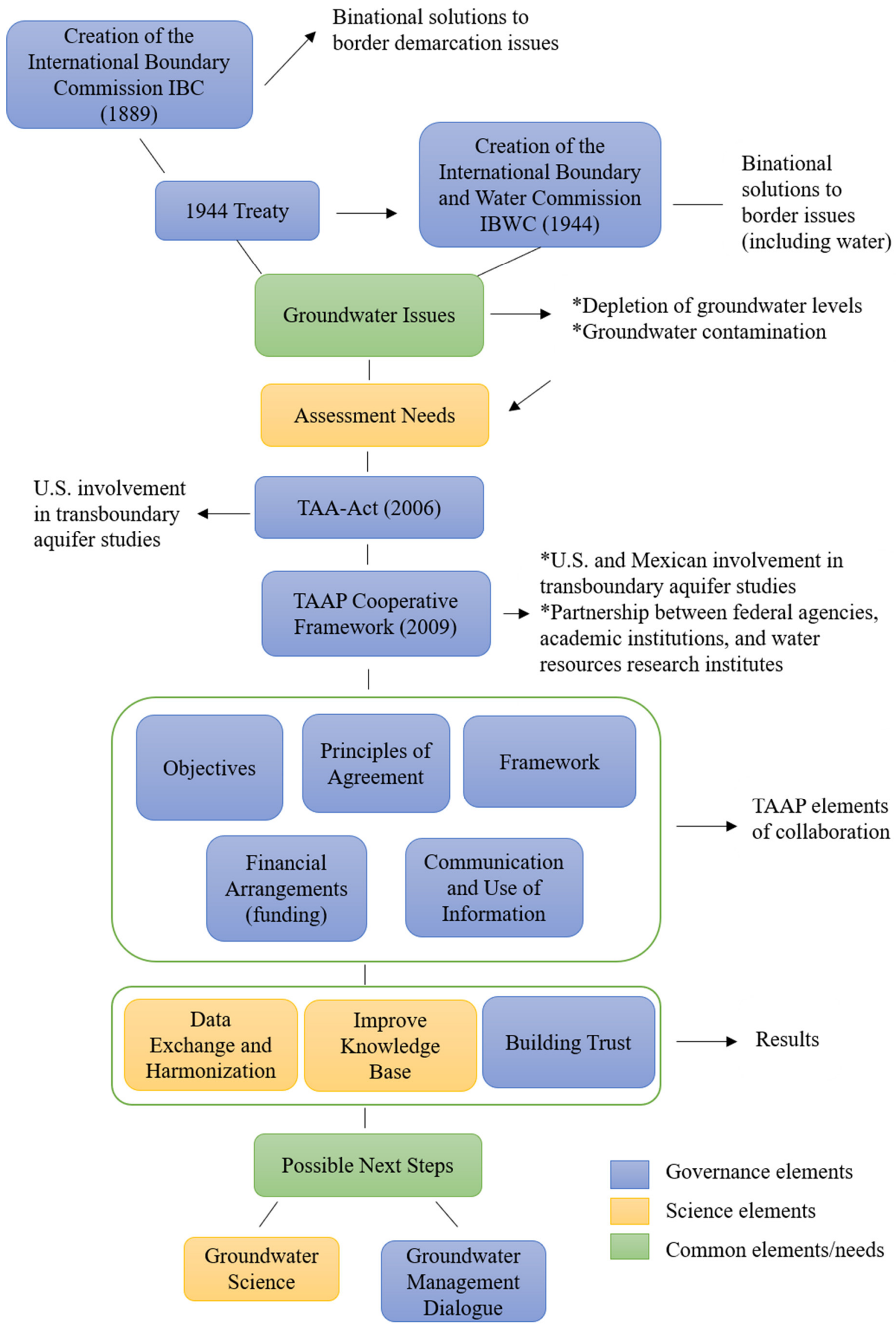

Figure 2. Evolution of the United States-Mexico Transboundary Aquifer Assessment Program. 


\section{Discussion}

Currently, there is no groundwater treaty between the United States and Mexico. The 1944 Water Treaty regarding the Utilization of Waters of the Colorado and Tijuana Rivers and of the Rio Grande (1944 Treaty) is the primary surface-water-allocating mechanism for the two countries. The treaty, however, does not mention groundwater. The Joint Report of the Principal Engineers Regarding the Joint Cooperative Process United States-Mexico for the Transboundary Aquifer Assessment Program (TAAP Cooperative Framework) is a case of groundwater collaboration for the assessment of the U.S.-Mexico transboundary aquifers of focus: the Santa Cruz, San Pedro, Mesilla, and Hueco Bolson aquifers. However, at least 36 transboundary aquifers shared by the United States and Mexico have been identified so far [25].

Relevant studies on U.S.-Mexico groundwater governance have analyzed (1) the intranational institutions for the management of shared groundwater resources [22]; (2) the importance of institutional asymmetries for transboundary aquifer assessment [20]; (3) the institutional assessment of the Transboundary Santa Cruz and San Pedro Aquifers [21], and; (4) the management perspectives for the shared aquifers of the United States and Mexico [25]. While most of these studies discussed the outcomes, advantages, and disadvantages of the TAAP Cooperative Framework and the program itself, the components of the TAAP Cooperative Framework have not been analyzed as a model for groundwater collaboration.

This study analyzed the TAAP Cooperative Framework as a guide for furthering scientific assessment in areas that have not entered into formal agreements for binational collaborative studies. Through literature review and analysis of existing transboundary groundwater management agreements, we found that common elements of collaboration between the TAAP Cooperative Framework and existing groundwater management agreements include provisions for the exchange of data, concurrence for binational aquifer assessment, the establishment of technical advisory committees and technical groups, and respect for the legal framework and jurisdictional requirements of each country.

The TAAP exhibits several features that enable groundwater collaboration: existing legal mechanisms, previous water collaboration, third-party involvement, scientific research, and funding mechanisms. Additionally, the framework is consistent with four UN Draft Articles on the Law of Transboundary Aquifers, findings that may indicate the readiness of the two countries to move on to a next step: to implement additional aquifer assessment along the U.S.-Mexico border or to initiate dialogue toward the development of groundwater management mechanisms.

Some scholars have argued that the TAAP marginalizes issues such as groundwater rights and management [60] and lacks a binding capacity (personal communication, 2020), and we agree with this premise. The information generated through the TAAP is "solely for the purpose of expanding knowledge" [20]. However, the present study has found that scientific assessment is a prior step for the development of groundwater management agreements. In fact, interviews with experts on transboundary waters explored two ways in which the TAAP could guide groundwater management: through local agreements for the management of specific aquifer systems or through a regional agreement that guides the use of groundwater resources in the border region. In any case, lessons from the TAAP Cooperative Framework and the program itself remain as a model of robust binational groundwater collaboration with principles that have the potential to guide future groundwater assessment and management not just along the U.S.-Mexico border, but across the world.

\section{Conclusions}

The United States and Mexico share rivers, basins, and aquifers. Yet they do not share a water management agreement that suits the needs of the border communities that completely rely on groundwater resources. Challenges for managing shared groundwater in the region include population growth, industrialization, increase in agriculture, contam- 
ination, increase in surface water and groundwater demands, and climate uncertainties. These challenges indicate that some sort of binational arrangement is needed to protect and manage the shared groundwater resources. However, the topic has only been mentioned twice since the IBWC was created. Almost five decades after the signing of Minute 242 and three decades after the development of the Bellagio Draft Treaty, there has been no effort to establish a comprehensive groundwater agreement. Meanwhile, efforts toward increasing understanding of the U.S.-Mexico transboundary aquifers have taken place. This study analyzed the TAAP Cooperative Framework as a guide for furthering scientific assessment in areas that have not entered into formal agreements for binational collaborative studies. To achieve this, we compared the elements of collaboration present within the TAAP Cooperative Framework and six transboundary aquifer agreements around the world.

From this analysis, we found that five elements were particularly relevant as common features of collaboration that align with the TAAP Cooperative Framework: (1) the presence of data exchange provisions, (2) the concurrence for binational aquifer assessment, (3) the establishment of technical advisory committees, which occurred with all of the aquifers, (4) the presence of technical groups, and (5) respect for the legal framework and jurisdictional requirements of the involved countries. Expert interviews also served to identify lessons learned from the TAAP and global challenges for groundwater collaboration, which included the importance of trust-building between border communities sharing water resources, groundwater assessment, and a pre-existing framework for collaboration. It was also suggested that the TAAP principles are general enough to be used as a guide to promoting additional groundwater collaboration for the assessment of other transboundary aquifers in Mexico and the United States and around the world. Yet, the applicability of the TAAP Cooperative Framework will depend largely on the unique circumstances of the involved countries.

We conclude for several reasons that the transboundary aquifer assessment efforts following the TAAP Cooperative Framework represent a model for others wishing to engage in transboundary aquifer assessment. The TAAP Cooperative Framework is a concisely written and readily available document that has been successfully approved and signed by two countries. It has promoted productive scientific collaboration between the United States and Mexico in a manner consistent with the Draft Articles on the Law of Transboundary Aquifers (UN Draft Articles). Its elements are also consistent with the information gathering portion of successful groundwater management agreements around the world. It includes funding and communication provisions that are uncommon in existing international agreements but that facilitate groundwater cooperation, as made evident by the collaboration to date. Finally, according to the TAAP Cooperative Framework, either of the two countries can propose an aquifer of focus, meaning that there is no need to develop a new cooperative framework for assessing additional transboundary aquifers shared by the United States and Mexico.

The present study finds evidence of successful outcomes within the TAAP Cooperative Framework consistent with available transboundary groundwater management agreements, demonstrating that the approach is suited to serve as a model for others wishing to engage in transborder aquifer assessments worldwide. Furthermore, the principles of the TAAP Cooperative Framework include elements that promote trust between the United States and Mexico (e.g., data sharing, development of binational aquifer assessment activities, the establishment of technical advisory committees, and establishment of technical groups). These and the rest of the TAAP elements of collaboration can help to establish the meaningful and robust binational cooperation necessary for the development of U.S.-Mexico groundwater management agreements at the aquifer level. 
Author Contributions: Conceptualization, E.M.T.-V. and S.B.M.; supervision, S.B.M.; methodology, E.M.T.-V. and S.B.M.; validation, E.M.T.-V. and S.B.M.; formal analysis, E.M.T.-V.; investigation, E.M.T.-V.; resources, E.M.T.-V.; data curation, E.M.T.-V.; writing—original draft preparation, E.M.T.V.; writing-review and editing, S.B.M.; visualization, E.M.T.-V. and S.B.M.; project administration, S.B.M.; funding acquisition, S.B.M. All authors have read and agreed to the published version of the manuscript.

Funding: This work was partially funded by the U.S. Geological Survey (funding authorized by P.L. 109-448) Award Number G17AC00439 for the Transboundary Aquifer Assessment Program, the Babbitt Dissertation Fellowship Program from the Lincoln Institute of Land and Policy, and the Consejo Nacional de Ciencia y Tecnología (CONACYT).

Institutional Review Board Statement: This project has been reviewed and approved by an IRB Chair or designee from the University of Arizona (protocol number 1809938973, approved on 17 October 2018).

Informed Consent Statement: Informed consent was obtained from all subjects involved in the study.

Data Availability Statement: Data sharing is not applicable to this study. The information shared during the interview process is confidential and cannot be shared with the public.

Acknowledgments: The authors wish to express their thanks to all the people that contributed to the development of this study via interviews, revisions, and through data sharing.

Conflicts of Interest: The authors declare no conflict of interest. The funders had no role in the design of the study; in the collection, analyses, or interpretation of data; in the writing of the manuscript, or in the decision to publish the results.

\section{References}

1. Fried, J.; Ganoulis, J. Transboundary Groundwater Resources: Sustainable Management and Conflict Resolution; Lambert Academic Publishing: Saarbrücken, Germany, 2016.

2. Earle, A.; Neal, M.J. Inclusive Transboundary Water Governance. In Freshwater Governance for the 21st Century; Global Issues in Water Policy; Springer: Cham, Switzerland, 2017; Volume 6, pp. 145-158.

3. IGRAC (International Groundwater Resources Assessment Centre); UNESCO-IHP (UNESCO International Hydrological Programme). Transboundary Aquifer of the World [Map]: Update 2020: Scale 1: 50000 000; IGRAC: Delft, The Netherlands, 2020.

4. Giordano, M.; Drieschova, A.; Duncan, J.A.; Sayama, Y.; de Stefano, L.; Wolf, A.T. A review of the evolution and state of transboundary freshwater treaties. Int. Environ. Agreem. Polit. Law Econ. 2014, 14, 245-264. [CrossRef]

5. Petersen-Perlman, J.D.; Wolf, A.T. Getting to the First Handshake: Enhancing Security by Initiating Cooperation in Transboundary River Basins. J. Am. Water Resour. Assoc. 2015, 51, 1688-1707. [CrossRef]

6. McCracken, M.; Wolf, A.T. Updating the Register of International River Basins of the world. Int. J. Water Resour. Dev. 2019, 35, 732-782. [CrossRef]

7. Lopez-Gunn, E.; Jarvis, W.T. Groundwater governance and the Law of the Hidden Sea. Water Policy 2009, 11, 742-762. [CrossRef]

8. Megdal, S.B.; Petersen-Perlman, J.D. Groundwater Governance and Assessment in a Transboundary Setting. In Lake Governance; Grover, V.I., Ed.; Series: Water: Emerging Issues and Innovative Responses I "A Science Publishers Book”; CRC Press: Boca Raton, FL, USA, 2018; pp. 40-64.

9. Callegary, J.B.; Megdal, S.B.; Tapia Villaseñor, E.M.; Petersen-Perlman, J.D.; Minjarez Sosa, J.I.; Monreal Saavedra, R.; Gray, F.; Grijalva Noriega, F.J. Findings and lessons learned from the assessment of the Mexico-United States transboundary San Pedro and Santa Cruz aquifers: The utility of social science in applied hydrologic research. J. Hydrol. Reg. Stud. 2018, 20, 60-73. [CrossRef]

10. De Chaisemartin, M.; Varady, R.G.; Megdal, S.B.; Conti, K.I.; van der Gun, J.; Merla, A.; Nijsten, G.; Scheibler, F. Addresing the Groundwater Governance Challenge. In Freshwater Governance for the 21st Century; Springer International Publishing: Cham, Switzerland, 2017; pp. 205-227.

11. Sanchez, R.; Eckstein, G. The path towards groundwater management in the borderlands of Mexico and Texas. Wiley Interdiscip. Rev. Water 2019, 7, e1399. [CrossRef]

12. IBWC. U.S. IBWC. Available online: https:/ /ibwc.gov/home.html (accessed on 25 December 2020).

13. Varady, R.G.; Scott, C.A.; Wilder, M.; Morehouse, B.; Pineda Pablos, N.; Garfin, G.M. Transboundary adaptive management to reduce climate-change vulnerability in the western U.S.-Mexico border region. Environ. Sci. Policy 2013, 26, 102-112. [CrossRef]

14. Updike, R.G.; Ellis, E.G.; Page, W.R.; Parker, M.J.; Hestbeck, J.B.; Horak, W.F. United States-Mexican Borderlands: Facing Tomorrow's Challenges through USGS Science; U.S. Geological Survey Circular 1380; U.S. Department of the Interior, U.S. Geological Survey: Reston, VA, USA, 2013; p. 336.

15. Wilder, M.; Scott, C.A.; Pineda Pablos, N.; Varady, R.G.; Garfin, G.M.; McEvoy, J. Adapting Across Boundaries: Climate Change, Social Learning, and Resilience in the U.S.-Mexico Border Region. Ann. Assoc. Am. Geogr. 2010, 100, 917-928. [CrossRef] 
16. Mumme, S.P. Minute 242 and beyond: Challenges and opportunities for managing transboundary groundwater on the Mexico-US border. Nat. Resour. J. 2000, 40, 341-378.

17. Puri, S.; Appelgren, B.; Arnold, G.; Aureli, A.; Burchi, S.; Burke, J.; Margat, J.; Pallas, P. Internationally Shared (Transboundary) Aquifer Resources Management; United Nations Educational, Scientific and Cultural Organization: Paris, France, 2001.

18. Conti, K.I. Factors Engabling Transboundary Aquifer Cooperation: A Global Analysis; IGRAC: Delft, The Netherlands, $2014 ;$ p. 108.

19. Megdal, S.B. The Cooperative Framework for the Transboundary Aquifer Assessment Program: A Model for Collaborative Transborder Studies. Ariz. Water Resour. 2017, 25, 1-2.

20. IBWC. Joint Report of the Principal Engineers Regarding Joint Cooperative Process. United States-Mexico for the Transboundary Aquifer Assessment Program. 2009. Available online: wrrc.arizona.edu/sites/wrrc.arizona.edu/files/images/Joint-ReportTAAP-8-19-09.pdf (accessed on 25 December 2020).

21. Megdal, B.S.; Scott, C.A. The Importance of Institutional Asymmetries to the Development of Binational Aquifer Assessment Programs: The Arizona-Sonora Experience. Water 2011, 3, 949-963. [CrossRef]

22. Megdal, S.B.; Sención, R.; Scott, C.A.; Díaz, F.; Oroz, L.; Callegary, J.; Varady, R.G. Institutional Assessment of the Transboundary Santa Cruz and San Pedro Aquifers on the United States-Mexico Border. In Proceedings of the ISARM2010 International Conference, Paris, France, 6-8 December 2010.

23. Milman, A.; Scott, C.A. Beneath the surface: Intranational institutions and management of the United States-Mexico transboundary Santa Cruz aquifer. Environ. Plan. C Gov. Policy 2010, 28, 528-551. [CrossRef]

24. Sanchez, R.; Lopez, V.; Eckstein, G. Identifying and characterizing transboundary aquifers along the Mexico-US border: An. initial assessment. J. Hydrol. 2016, 535, 101-119.

25. Sanchez, R.; Eckstein, G. Aquifers Shared Between Mexico and the United States: Management Perspectives and Their Transboundary Nature. Groundwater 2017, 55, 495-505. [CrossRef] [PubMed]

26. Villar, P.C. International cooperation on transboundary aquifers in South. America and the Guarani Aquifer case. Rev. Bras. De Politica Int. 2016, 59. [CrossRef]

27. Movilla Pateiro, L. Ad hoc legal mechanisms governing transboundary aquifers: Current status and future prospects. Water Int. 2016, 41, 851-865. [CrossRef]

28. Etikan, I. Comparison of Convenience Sampling and Purposive Sampling. Am. J. Theor. Appl. Stat. 2016, 5, 1-4. [CrossRef]

29. Matsumoto, K. Transboundary Groundwater and International Law: Past Practices and Current Implications; Oregon State University: Corvallis, OR, USA, 2004.

30. Jarvis, T.; Giordano, M.; Puri, S.; Matsumoto, K.; Wolf, A. International Borders, Ground Water Flow, and Hydroschizophrenia. Ground Water 2005, 43, 764-770. [CrossRef]

31. Albrecht, T.R.; Varady, R.G.; Zuniga-Teran, A.A.; Gerlak, A.K.; Staddon, C. Governing a shared hidden resource: A review of governance mechanisms for transboundary groundwater security. Water Secur. 2017, 2, 43-56. [CrossRef]

32. Eckstein, G.; Sindico, F. The Law of Transboundary Aquifers: Many Ways of Going Forward, but Only One Way of Standing Still: The Law of Transboundary Aquifers. Rev. Eur. Comp. Int. Environ. Law 2014, 23, 32-42. [CrossRef]

33. UNGA. United Nations General Assembly Resolution 63/124 (2008) on the Law of Transboundary Aquifers. See Also the Subsequent UNGA Resolutions 66/104 (2011), 68/118 (2013), 71/150 (2016), 74/85 (2019). Available online: https:/ /www. internationalwaterlaw.org/documents/intldocs/) (accessed on 25 January 2021).

34. Zeitoun, M. Power and Water in the Middle East: The Hidden Politics of the Palestinian-Israeli Water Conflict; I.B. Tauris: London, UK; New York, NY, USA, 2008.

35. Allan, J.A. Water in the environment/socio-economic development discourse: Sustainability, changing management paradigms and policy responses in a global system. Gov. Oppos. 2005, 40, 181-199. [CrossRef]

36. Neal, M.J.; Greco, F.; Connell, D.; Conrad, J. The social-environmental justice of groundwater governance. In Integrated GroundWater Management; Springer: Cham, Switzerland, 2016; pp. 253-272.

37. UN-Water. Step-by-Step Monitoring Methodology for Indicator 6.5.2. 2016. Available online: http://www.unwater.org/ publications/step-step-methodology-monitoring-transboundary-cooperation-6--5-2/ (accessed on 17 February 2021).

38. Hussein, H.; Menga, F.; Greco, F. Monitoring Transboundary Water Cooperation in SDG 6.5.2: How a Critical Hydropolitics Approach Can. Spot Inequitable Outcomes. Sustainability 2018, 10, 3640.

39. Internationally Shared Aquifer Resources Management (ISARM), United Nations Educational Scientific and Cultural Organization (UNESCO), International Hydrological Programme (IHP), Paraguay Ratified the Guaraní Aquifer System Agreement. Available online: https:/ / isarm.org/paraguay-has-ratified-guaran\%C3\%AD-aquifer-system-agreement (accessed on 25 January 2021).

40. Hussein, H. The Guarani Aquifer System, highly present but not high profile: A hydropolitical analysis of transboundary groundwater governance. Environ. Sci. Policy 2018, 83, 54-62. [CrossRef]

41. Sugg, Z.P.; Varady, R.G.; Gerlak, A.K.; de Grenade, R. Transboundary groundwater governance in the Guarani Aquifer System: Reflections from a survey of global and regional experts. Water Int. 2015, 40, 377-400. [CrossRef]

42. Acuerdo sobre el Acuífero Guaraní. Acuerdo sobre el Acuífero Guaraní Suscipto por la República de Argentina, La República Federativa de Brasil, La República de Paraguay y La República Oriental del Uruguay en San Juan, Argentina, August 2, 2010; Secretaria. Carpeta no 728 de 2011, Repartido no 486; República Oriental del Uruguay, Cámara de Senadores: Montevideo, Uruguay, 2012 ; p. 31.

43. De los Cobos, G. The Genevese transboundary aquifer (Switzerland-France): The secret of 40 years of successful management. $J$. Hydrol. Reg. Stud. 2018, 20, 116-127. [CrossRef] 
44. Eckstein, G. Managing buried treasure across frontiers: The international Law of Transboundary Aquifers. Water Int. 2011, 36, 573-583. [CrossRef]

45. Garner, E.L. Factors identifying aquifers with a high probability of management success. Water Int. 2019, 44, 354-362. [CrossRef]

46. De los Cobos, G. A historical overview of Geneva's artificial recharge system and its crisis management plans for future usage. Environ. Earth Sci. 2015, 73, 7825-7831. [CrossRef]

47. UNESCO. Atlas of Transboundary Aquifers: Global Maps, Regional Cooperation and Local Inventories; UNESCO: Paris, France, 2009; p. 322.

48. Burchi, S.; Mechlem, K. Groundwater in International Law: Compilation of Treaties and Other Legal Instruments; FAO: Rome, Italy; UNESCO: Paris, France, 2015; Volume 20, pp. 15-20.

49. Republic of Mali, Republic of Niger, Federal Republic of Nigeria. Bamako Declaration of the Ministers in Charge of Water Resources of the Countries Sharing the Iullemeden Aquifer System (Mali, Niger, Nigeria); Republic of Mali: Bamako, Mali, 2009. Available online: internationalwaterlaw.org/documents/regionaldocs/Iullemeden_Bamako_Declaration-2009.pdf (accessed on 25 December 2020).

50. Burchi, S. Legal frameworks for the governance of international transboundary aquifers: Pre- and post-ISARM experience. J. Hydrol. Reg. Stud. 2018, 20, 15-20. [CrossRef]

51. Cascão, A.E.; Zeitoun, M. Power, hegemony and critical hydropolitics. Transbound. Water Manag. Princ. Pract. 2010, $27,42$.

52. Gaglio, E. The Nubian Sandstone Aquifer: An. Institutional Approach to Water Management. Calif. West. Int. Law J. 2016, 47, 32.

53. Grossman, M. Cooperation on Africa's International Waterbodies: Information Needs and the Role of Information-Sharing. In Transboundary Water Management in Africa: Challenges for Development Cooperation; Deutsches Institut für Entwicklungspolitick: Bonn, Germany, 2006.

54. Ferragina, E.; Greco, F. The Disi project: An internal/external analysis. Water Int. 2008, 33, 451-463. [CrossRef]

55. Eckstein, G. The Newest Transboundary Aquifer Agreement: Jordan and Saudi Arabia Cooperate over the Al-Saq /Al-Disi Aquifer. International Water Law Project Blog 2015. Available online: https://www.internationalwaterlaw.org/blog/2015/08/31 /the-newest-transboundary-aquifer-agreement-jordan-and-saudi-arabia-cooperate-over-the-al-sag-al-disi-aquifer/ (accessed on 25 December 2020).

56. Mumme, S. The 1944 U.S.-Mexico Water Treaty as a Constitutional Document; Rice University's Baker Institute for Public Policy: Houston, TX, USA, 2019; p. 15.

57. IBWC. Minute No. 242 Permanent and Definitive Solution to the International Problem of the Salinity of the Colorado River. 1973. Available online: https:/ / www.ibwc.gov/Files/Minutes/Min242.pdf (accessed on 25 December 2020).

58. IBWC. Minute No. 323 Extension of Cooperative Measures and Adoption of a Binatioal Water Scarcity Contingency Plan in the Colorado River Basin. 2017. Available online: https:/ / www.ibwc.gov /Files/Minutes/Min323.pdf (accessed on 25 December 2020).

59. O'Leary, M.C. The Bellagio Draft Treaty as a Tool for Solving Border Groundwater Issues. United States-Mex. Law J. 2003, 11, 5.

60. Kuri, G.H.; Rivera, J.J.C.; Huizar, R.Á. Evaluación crítica del acuífero transfronterizo río San Pedro. Reg. Cohes. 2019, 9, 61-85. [CrossRef]

61. Petersen-Perlman, J.D. The Transboundary Aquifer Assessment Program: Past, Present, and Future US-Mexico Border Water Summit; Water Resources Research Center: El Paso, TX, USA, 2018. 